\title{
ERRATUM
}

\section{Modes of relating to contingency: An exploration of experiences in advanced cancer patients- ERRATUM}

RENSKE KRUIZINGA, IRIS D. HARTOG, MICHAEL SCHERER-RATH, HANS SCHILDERMAN, AND HANNEKE VAN LAARHOVEN

DOI: https://doi.org/10.1017/S1478951516000936, Published by Cambridge University Press, 20 December 2016.

The academic degree for authors Scherer-Rath and Schilderman was mistakenly listed as "M.D.”. The proper byline should read as follows:

Renske Kruizinga, M.A., Iris D. Hartog, M.A., Michael Scherer-Rath, PH.D., Hans Schilderman, PH.D., and Hanneke Van Laarhoven, M.D., Ph.D.

The author and publisher regret this error.

\section{REFERENCE}

Kruizinga, R., Hartog, I.D., Scherer-Rath, M., et al. (2016). Modes of relating to contingency: An exploration of experiences in advanced cancer patients. Palliative and Supportive Care. doi: 10.1017/S1478951516000936. 